\title{
Carbon Footprint in Meat Production and Supply Chains
}

\author{
Roberto Schroeder ${ }^{1}$, Luís Kluwe Aguiar ${ }^{2}$ and Richard Baines ${ }^{3}$ \\ 1. Ministry of Agriculture, Livestock and Food Supply, Porto Alegre, Rio Grande do Sul 91760-450, Brazil \\ 2. School of Business, Royal Agricultural College, Cirencester, Gloucestershire GL7 6JS, England \\ 3. School of Agriculture, The Royal Agricultural College, Cirencester, Gloucestershire GL7 6JS, England
}

Received: October 22, 2011 / Published: November 20, 2012.

\begin{abstract}
All human activities, including food production, are potentially sources of greenhouse gases (GHG) emissions. In order to provide a better understanding of how to mitigate the GHG emissions, an inventory based on different beef supply chains in the United Kingdom and in Brazil was carried out. The carbon footprint of the beef systems was calculated based on the life cycle assessment methodology. Total emissions per kg of bone-free meat were calculated at being 33.85, 33.99 and $45.17 \mathrm{~kg}$ of $\mathrm{CO}_{2} \mathrm{e}-100 / \mathrm{kg}_{\text {for }} \mathrm{UK}_{1}$, $\mathrm{UK}_{2}$ and Brazil farm units, respectively. Based on an average potential for carbon sequestration rate at the proportion of 12:44 for $\mathrm{C}: \mathrm{CO}_{2}$ conversion for well managed grasslands, there is a potential sequestration of $1,980 \mathrm{~kg}$ of $\mathrm{CO}_{2} / \mathrm{ha} / \mathrm{year}$. This would potentially reduce the total emissions value for the three distinct supply chains as being 29.4, 28.4 and $25.4 \mathrm{~kg} \mathrm{CO}_{2}$-e 100/kg of bone-free meat for the cases of $\mathrm{UK}_{1}, \mathrm{UK}_{2}$ and Brazil, respectively.
\end{abstract}

Key words: Life cycle assessment, GHG emissions, carbon footprint, supply chains, beef.

\section{Introduction}

Since the outset of the industrial revolution (post 1750s) [1], it is estimated that the amount of carbon dioxide in the atmosphere has increased by $35 \%$ with the tropospheric concentration of carbon dioxide $\left(\mathrm{CO}_{2}\right)$ reaching its highest in 450,000 years. All human activities cause GHG emissions [2] that lead to climate change. The case of the production and supply of food, which has led to mainly emissions of $\mathrm{CO}_{2}$, methane $\left(\mathrm{CH}_{4}\right)$ and nitrous oxide $\left(\mathrm{N}_{2} \mathrm{O}\right)$ into the environment, is not different.

In farm systems, GHG emissions derive from primarily three main sources. Whilst carbon dioxide is produced as a result of the generation of energy by the combustion of fossil fuels, methane is mainly produced by the biological processes of livestock, and nitrous oxide is largely derived from the use of synthetic fertilisers used in pasture improvement [3]. As a result of the analysis of GHG emissions relating to both

\footnotetext{
Corresponding author: Roberto Schroeder, M.Sc., research field: rural development. E-mail: roberto.schroeder@agricultura.gov.br.
}

livestock production and supply chain activities it has been revealed that most $\mathrm{CO}_{2}$-related derived from activities such as feed production, livestock rearing, meat processing and refrigerated transportation [4]. Most $\mathrm{N}_{2} \mathrm{O}$ emissions were derived from feed-related fertilizers, from aquatic sources following the use of chemical fertilizers, from nitrogen waste in livestock production chains, from manure either stored, spread or deposited on pastures and $\mathrm{CH}_{4}$ emissions from animals' enteric fermentation and the production of manure (Table 1).

In addition, gases such as $\mathrm{CO}_{2}, \mathrm{CH}_{4}$ and $\mathrm{N}_{2} \mathrm{O}$ are attributed to have also caused warming effect in the natural environment. Other gases such as halocarbons and sulphur hexafluoride $\left(\mathrm{SF}_{6}\right)$ [5] have also contributed to the rise of the global temperature. As such, global warming and its consequent climate change could be a serious global threat and demands an urgent global response [6].

Each GHG has a different global warning potential (GWP). The GWP has been defined as an index that measures the radioactive forcing of a unit mass of a 
Table 1 GHG concentrations and GWP [7].

\begin{tabular}{llll}
\hline Gas & $\begin{array}{l}\text { Pre 1750s } \\
\text { tropospheric concentration }\end{array}$ & Recent tropospheric concentration & $\begin{array}{l}\text { GWP } \\
(100 \text { year time horizon })\end{array}$ \\
\hline Carbon dioxide $\left(\mathrm{CO}_{2}\right)$ & $280 \mathrm{ppm}$ & $348.8 \mathrm{ppm}$ & $1 \mathrm{CO}_{2} \mathrm{e}-100$ \\
Methane $\left(\mathrm{CH}_{4}\right)$ & $700 \mathrm{ppb}$ & $1803 \mathrm{ppb}$ & $25 \mathrm{CO}_{2} \mathrm{e}-100$ \\
Nitrous oxide $\left(\mathrm{N}_{2} \mathrm{O}\right)$ & $270 \mathrm{ppb}$ & $321.5 \mathrm{ppb}$ & $298 \mathrm{CO}_{2} \mathrm{e}-100$ \\
\hline
\end{tabular}

given well-mixed greenhouse gas in the present-day atmosphere integrated over a chosen time horizon, relative to that of carbon dioxide. The GWP represents the combined effect of the differing times these gases remain in the atmosphere and their relative effectiveness in absorbing outgoing thermal infrared radiation [8]. As the GWP is a relation between the effect of the other GHG and the $\mathrm{CO}_{2}$, and is expressed normally in $\mathrm{CO}_{2}$ equivalent in 100 year time $\left(\mathrm{CO}_{2} \mathrm{e}-100\right)$. Whilst carbon dioxide has the highest direct global warming impact because its concentration and emitted quantities are much higher than any other GHG, methane is the second most important one [4].

Furthermore, it is understood that the carbon footprint results from the total amount of GHG emissions for which an individual, organization, event or a good has been responsible for producing and has been characteristically expressed in $\mathrm{CO}_{2}$ equivalents [2]. The values of carbon footprint expressed in $\mathrm{CO}_{2}$ equivalent quantities are remarkably very similar to global warming potential which, on its turn has been an indicator used in life cycle assessments (LCA) [9]. As the carbon footprint has had a much broader appeal and it made sense to perform the life cycle assessment based on established international standards.

In agricultural systems, GHG emissions have been derived from $\mathrm{CO}_{2}$ emission and bad soil management. Nonetheless, agricultural "on farm” systems could be at the same time sources of GHG emissions as well as act as carbon repositories. The latter emissions could be attributed to two sources: firstly, from the depletion of organic matter with its consequent further emission of carbon, and secondly, owed to the change of land use, when considering the carbon sink being lower than the previous one. In this case, it is argued that well managed soils could have their carbon content actually increased. In view of this, it is important to obtain a more precise account of $\mathrm{CO}_{2}$-equivalent emitted and sequestrated during the production of an agricultural product [10].

Emissions from Brazilian beef production for Brazilian bone-free meat at Stockholm market in Sweden were found to be $41 \mathrm{~kg}$ of $\mathrm{CO}_{2} \mathrm{e}$ per $\mathrm{kg}$ [11]. That was slightly inferior than Brazilian meat offered in markets in London at $45.19 \mathrm{~kg}$ of $\mathrm{CO}_{2} \mathrm{e}-100$ per kg.

Yet, when comparing the energy turnover from meat produced in Argentina and imported to Germany against local German produced meat, it was found that Argentinean meat had released $0.83 \mathrm{~kg}$ of $\mathrm{CO}_{2}$ per $\mathrm{kg}$ of meat, whilst local German meat from five different sources had released on average $1.79 \mathrm{~kg}$ of $\mathrm{CO}_{2}$ per $\mathrm{kg}$ of meat [12]. Moreover, in the greenhouse gases emission from livestock sector "Interim Report Phase 1”, a study commissioned by the European Commission, it was found that GHG emissions for the three main meat products imported into the European Union, i.e., lamb from New Zealand, beef and chicken from Brazil presented levels of 33, 80 and $1.2 \mathrm{~kg}$ of $\mathrm{CO}_{2}$-eq/kg of meat, respectively [13].

As seen before, on-farm food production systems are at the same time sources of GHG emission and also points of carbon sequestration. When considering the potential for soil carbon sequestration and its multiple benefits in dry land grazing systems [14], an average potential for carbon sequestration in well-managed grassland have been estimated at being $0.54 \mathrm{Mg}$ of carbon/ha/year [15]. It is estimated that management improvement alone would allow for the highest sequestration rates which would occur during the first 40 years of intervention. The sequestration rate applied at the proportion of 12:44 for $\mathrm{C}: \mathrm{CO}_{2}$ conversion results in a potential sequestration of $1,980 \mathrm{~kg}$ of $\mathrm{CO}_{2} / \mathrm{ha} /$ year. 
As a result, the balance between emissions and sequestration should be considered.

In the light of much media misconceptions about carbon foot print of imported food stuff, especially, beef into the United Kingdom, the aim of this study was to compare the carbon footprint of Brazilian beef to that of beef produced in the United Kingdom. Firstly, GHG emissions from "on farm" systems as well as from transport and processing activities throughout the supply chains were calculated. Secondly, a discussion of the consequences on GHG emissions of the different farming systems was carried out in an attempt to see how these emissions were affected by the specificities of each production and supply systems. It was expected that obtaining an inventory of GHG emissions from different production and supply chains might one day help to mitigate these emissions.

Next, the method and the procedures used in this study are described followed by a section where the results will be presented. Finally, a discussion and conclusions as well as some managerial implications are synthesized.

\section{Methods}

The LCA was proposed a methodological framework for estimating and assessing the environmental impact attributable to a life cycle of a product [16]. The LCA ought to be performed based on international standards already available in order to have a consistent and comparable result. The public available specification PAS-2050, from the British standard institution (BSi), as the most notable individual methodology [9] has been considered in this study. The LCA comprised of the analysis of green house gases emissions throughout the various segments of a supply chain from primary production to end use and disposal [17]. The LCA consisted of tabulating the emissions, the consumption of resources and other environmental exchange at every relevant stage in the life cycle of any given product, from "cradle-to-grave". It comprised of a powerful set of tools for quantifying, evaluating, comparing, and improving goods and services in terms of their potential environmental impact.

To calculate the carbon footprints based on the LCA methodology, data from three beef farms and from their respective supply chains in two countries, i.e., the UK and Brazil were considered. The farms studied were located in Gloucestershire, UK, and in the State of Rio Grande do Sul, Brazil. The farms were selected for being exclusively representative of beef cattle and cereal production systems under complete beef cattle cycle production (from calving to finishing). The Southern-most state of Rio Grande do Sul in Brazil has traditionally been a cattle producer of European breeds since early colonisers. Being part of the Pampa biome, also present in both neighbouring countries, Uruguay and Argentina, have been characterized as natural grasslands. In spite of that state being larger in size than England and having a larger herd, the total amount of beef carcass and dairy produced is smaller $[18,19]$.

The starting point was the farm units. All the activities involving the animals, slaughter and meat processing, transportation and marketing throughout the supply chain until the final bone-free meat product reached the market in London were considered. Whenever necessary, default GHG emissions data from the intergovernmental panel on climate change (IPCC) was used. Owed to the studied units being small, only three farms with no statistical analysis could be carried out.

\subsection{Calculating the Greenhouse Gases Emission}

As stated in PAS 2050 [20, 21], the GHG emission assessment ought to be carried out in a manner that allowed for the mass of $\mathrm{CO}_{2}$-e to be reported per "functional unit" of the product. The functional unit was understood as "quantified performance of a product system for use as reference unit”. As for the purpose of the calculation of the greenhouse gases emissions in this study, the functional unit used was the 
kilogram expressed in kg of bone-free meat, which constituted the final product commonly available for the consumers. PAS-2050 considered land use change values to account GHG emissions, and stated that 5\% of the GHG emission arising from land use change had to be accounted annually for a period of up to 20 years after the change has taken place [21]. Furthermore, emissions from some parts of the production and supply chain that were accounted in kilogram of carcass would be converted to $\mathrm{kg}$ of bone-free meat using the following proportion:

$1 \mathrm{~kg}$ carcass weight (meat with bone) $=0.70 \mathrm{~kg}$ bone-free meat [22].

The GHG emissions were allocated to three different locations, according to each one of the production and supply chains: “On Farm”, "Slaughter" and “Transportation”. No emissions were accounted for energy consumption in the distribution centres and markets, owed to the fact that the activities related to these segments of the supply chain did not exclusively handled, but other products too.

\section{2 “On Farm” Emissions}

The “On Farm” emissions were also divided into three different categories: "cattle" (related to the emissions arising directly from the cattle or their excretions), “crops and pastures” (related to cereal, fodder and pasture production used for animal feeding), and "inputs related" (regarding inputs used in the production of cattle, but excluding those used in "crop" production). No emissions were considered from change in land use because no change had occurred in the previous 20 years in the three farms studied.

\subsection{1 “On Farm” Emissions from Cattle}

Ruminants are direct sources of methane emissions from enteric fermentation and methane and nitrous oxide from manure management and accumulation. To quantify the annual emission arising from the cattle in each farm, the average annual amount of cattle kept on the farms had to be calculated. Since at the point of data collection, the actual cattle present in the respective farms could not be representative of the annually kept herd, an adjustment was made based on the number of suckled cows, weaning rate and mortality rate after the first year of age. Despite the selected farms had performed, the complete cycle of beef production (from calving to finishing), a compensation factor was applied to account for the emissions relative to the herd. This was needed due to some animals which had been purchased and brought into the production system, therefore not staying throughout the whole cycle. This compensation factor was also based on the same weaning and mortality rates of the respective farms. Another compensation factor was also introduced to compensate for the different slaughter ages, based on a standard slaughter age of 24 months (e.g., a multiplication factor of 1.5 would be applied to the number of steers and heifers if the slaughter age was 30 months).

\section{Results}

The weaning rate, mortality rate after weaning, age of slaughter and average slaughter weight for steers and heifers for the three farms are presented in Table 2.

The summary of the calculated average herd maintained in each farm is presented in the Table 3.

\section{1 “On Farm" Emissions from Cattle Enteric Fermentation}

The calculation of the methane emissions from the cattle enteric fermentation was based on Tier 1 enteric fermentation emission factors for cattle [23]. Tier 1 is a simplified method that only requires livestock population data by animal species/category and climate region or temperature, in combination with IPCC default emission factors, to estimate emissions. The emission factor for other cattle in Western Europe was $57 \mathrm{~kg}$ of $\mathrm{CH}_{4} /$ head/year and in Latin America was 56 $\mathrm{kg}$ of $\mathrm{CH}_{4} /$ head/year. The total amount of $\mathrm{CH}_{4}$ emissions was divided by the total amount of carcass sold by each of the farms. The final value was obtained from multiplying the total amount of cattle sold by the 
Table 2 Weaning, mortality and slaughter data.

\begin{tabular}{lrrc}
\hline & $\mathrm{UK}_{1}$ & $\mathrm{UK}_{2}$ & Brazil \\
\hline Weaning rate (\%) & 95 & 98 & 80 \\
Mortality rate (\%) & 1 & 1 & 2.5 \\
Average age of slaughter (months) & 24 & 24 & 30 \\
$\begin{array}{l}\text { Average weight of slaughter for steers and } \\
\text { heifers (kg) }\end{array}$ & 624 & 600 & 465 \\
\hline
\end{tabular}

Table 3 Average annual amount of cattle maintained in the farms.

\begin{tabular}{lrrr}
\hline & $\mathrm{UK}_{1}$ & $\mathrm{UK}_{2}$ & Brazil \\
\hline Cows & 105 & 50 & 304 \\
Calves & 164 & 49 & 243 \\
Steers and heifers & 164 & 54 & 361 \\
Bulls & 3 & 2 & 14 \\
Compensation & 108 & 13 & 5 \\
Total & 514 & 167 & 927 \\
\hline
\end{tabular}

farm, the average weight of the cattle sold to the slaughterhouse and the following carcass rate (carcass weight/live weight $\times 100$ ) which came to $52 \%$ for steers and heifers, $48 \%$ for cows and 52\% for bulls. Following this, the total amount of methane emissions of each of the farms was divided by the annual total carcass weight sold by each of the farms. The resulting figures were then converted into $\mathrm{CO}_{2} \mathrm{e}-100$ per $\mathrm{kg}$ of meat produced as presented in Table 4. In the case of the farm unit "Brazil", 50 horses were also kept for use in the herding of the cattle. Following the guidelines, an additional $0.18 \mathrm{~kg} \mathrm{CO} \mathrm{CO}_{2} \mathrm{e}-100$ per $\mathrm{kg}$ of meat, resulting from $18 \mathrm{~kg}$ of $\mathrm{CH}_{4}$ emitted per head per year based on the equine enteric fermentation emission factor for Tier 1 method was added [23].

\section{2 “On Farm" Emissions from Cattle Manure Management (Methane)}

Methane is produced during the storage and treatment of manure and from manure deposited on pastures and crop fields. Tier 1 emission factor for methane emission from manure management [23] was applied to the annual average amount of cattle maintained on each of the farms. It was considered the emission factor of $6 \mathrm{~kg}$ of $\mathrm{CH}_{4} /$ head/year for "other cattle" in Western Europe under an average annual temperature of $9{ }^{\circ} \mathrm{C}[24]$ in Gloucestershire, and $1 \mathrm{~kg}$ of $\mathrm{CH}_{4} /$ head/year for "other cattle" in Latin America under an average annual temperature of $19{ }^{\circ} \mathrm{C}$ [24] for the municipality of Santa Maria in the State of Rio Grande do Sul. The total amount of methane emissions from manure of each of the farm units was divided by the total carcass weight sold by each of the farms on an annual basis. The value was then converted into $\mathrm{CO}_{2} \mathrm{e}-100$ per kg of meat produced, as shown in Table 5. For the farm unit "Brazil" where 15 horses were kept for helping with the herding of cattle, an additional $0.02 \mathrm{~kg} \mathrm{CO} \mathrm{CO}_{2} \mathrm{e}-100$ per $\mathrm{kg}$ of meat, resulting from 1.64 $\mathrm{kg}$ of $\mathrm{CH}_{4} /$ head/year based on the $\mathrm{CH}_{4}$ equine manure management emission based on factor for Tier 1 method in developing countries under $19{ }^{\circ} \mathrm{C}$ annual average temperature [23], was added.

\section{3 "On Farm" emissions from Cattle Manure} Management (Nitrous Oxide)

$\mathrm{N}_{2} \mathrm{O}$ is produced, directly and indirectly, during the storage and treatment of manure before it is applied to land and after this application. The $\mathrm{N}_{2} \mathrm{O}$ emissions were calculated combining the emissions of the manure management as well the emissions from the manure application/deposition in the soils. Since in the UK during the winter months, between November and February, the cattle was kept indoors, one third of the annual nitrogen excretion was treated as "solid storage" which received the corresponding emission factor of $0.0005 \mathrm{~kg}$ of $\mathrm{N}_{2} \mathrm{O} / \mathrm{kg}$ of $\mathrm{N}$ excreted for manure management [23]. As all the manure was spread in the farm fields for the purpose of soil fertilization, the total amount of nitrogen excretion produced for the purpose of $\mathrm{N}_{2} \mathrm{O}$ emission from managed soils was considered to be $0.02 \mathrm{~kg}$ of $\mathrm{N}_{2} \mathrm{O} / \mathrm{kg}$ of $\mathrm{N}$ excreted [23].

Nitrogen excretion arising from the cattle was calculated using the default value for nitrogen excretion rate of $0.33 \mathrm{~kg}$ of N/1000 $\mathrm{kg}$ of animal mass/day for "other cattle" in Western Europe, and $0.36 \mathrm{~kg}$ of N/1000 kg of animal mass/day for "other cattle” in Latin America [23]. Based on the farms' herd 
Table 4 Cattle enteric fermentation related $\mathrm{CO}_{2} \mathrm{e}-100$ emission $/ \mathrm{kg}$ of meat produced.

\begin{tabular}{llll}
\hline & $\mathrm{UK}_{1}$ & $\mathrm{UK}_{2}$ & Brazil \\
\hline Average cattle maintained (heads) & 514 & 167 & 927 \\
Emission factor $(\mathrm{kg} \mathrm{CH} /$ head/year) & 57 & 57 & 56 \\
Total $\mathrm{CH}_{4}$ emission (kg/year) & $29,313.77$ & $9,540.05$ & $52,845.16$ \\
Total carcass produced/sold (kg/year) & 55,904 & 16752 & 53100 \\
Carcass produced yearly per head of cattle maintained (kg/head) & 108.7 & 100.1 & 57.3 \\
$\mathrm{CO}_{2} \mathrm{e}-100 / \mathrm{kg}$ of meat $(\mathrm{kg})$ & 18.73 & 20.34 & 35.72 \\
\hline
\end{tabular}

Table 5 Manure management $\mathrm{CH}_{4}$ emissions converted to $\mathrm{CO}_{2} \mathrm{e}-100 / \mathrm{Kg}$ of meat produced.

\begin{tabular}{llll}
\hline & $\mathrm{UK}_{1}$ & $\mathrm{UK}_{2}$ & Brazil \\
\hline Total cattle mass $(\mathrm{kg})$ & $191,791.23$ & $66,051.44$ & $331,216.42$ \\
Excretion rate (kg of $\mathrm{N}_{2} \mathrm{O} / 1,000 \mathrm{~kg} /$ day) & 0.33 & 0.33 & 0.36 \\
Annual N excretion $(\mathrm{kg})$ & $23,101.25$ & $7,955.90$ & $43,521.84$ \\
$\mathrm{~N}_{2} \mathrm{O}$ emission factor $\left(\mathrm{kg} \mathrm{N} \mathrm{N}_{2} \mathrm{O} / \mathrm{kg} \mathrm{N}\right)$ & 0.02017 & 0.02017 & 0.02017 \\
$\mathrm{~N}_{2} \mathrm{O}$ emission $\left(\mathrm{kg} \mathrm{N} \mathrm{N}_{2} \mathrm{O} /\right.$ year) & 465.88 & 160.44 & 870.44 \\
Total carcass produced (kg/year) & 55,904 & 16,752 & 53,100 \\
$\mathrm{CO}_{2} \mathrm{e}-100 / \mathrm{kg}$ of meat $(\mathrm{kg})$ & 3.55 & 4.08 & 6.98 \\
\hline
\end{tabular}

data, the animal mass present on the farms was calculated by multiplying the number of cattle of each animal category by the average weight for the category. The total amount of Nitrous Oxide emissions from manure management for each of the farms was divided by the total carcass weight annually sold by each of the farms and finally converted to $\mathrm{CO}_{2} \mathrm{e}-100$ per $\mathrm{kg}$ of meat produced as presented in Table 6. For the farm unit "Brazil" where 15 horses (400 kg) are kept and used for the herding of the cattle, an additional $0.1 \mathrm{~kg} \mathrm{CO}_{2} \mathrm{e}-100$ per $\mathrm{kg}$ of meat resulting from $0.46 \mathrm{~kg}$ of $\mathrm{N}$ excretion/1,000 kg of mass/day (default value for horses in Latin America) and an emission factor for $\mathrm{N}_{2} \mathrm{O}$ manure management of $0.01 \mathrm{~kg}$ of $\mathrm{N}_{2} \mathrm{O} / \mathrm{kg}$ of $\mathrm{N}$ excreted for "other animals" in managed soils [23], was added.

\subsection{Total "On Farm" Emissions from Manure Management}

The total emissions converted to $\mathrm{CO}_{2} \mathrm{e}-100$ arising from manure management, combining $\mathrm{CH}_{4}$ and $\mathrm{N}_{2} \mathrm{O}$ emissions are shown in Table 7.

\section{5 "On Farm” Emissions from Crops and Pastures}

The calculations regarding the emissions arising from crops and pasture production used to feed the
Table 6 Manure management $\mathrm{N}_{2} \mathrm{O}$ emissions converted to $\mathrm{CO}_{2} \mathrm{e}-100$ emissions/kg of meat produced.

\begin{tabular}{|c|c|c|c|}
\hline & $\mathrm{UK}_{1}$ & $\mathrm{UK}_{2}$ & Brazil \\
\hline Average cattle maintained (heads) & 514 & 167 & 927 \\
\hline $\begin{array}{l}\text { Manure emission factor (kg } \\
\mathrm{CH}_{4} / \text { head/year) }\end{array}$ & 6 & 6 & 1 \\
\hline Total $\mathrm{CH}_{4}$ emission (kg/year) & $3,085.66$ & $1,004.22$ & 927.11 \\
\hline Total carcass produced (kg/year) & 55,904 & 16,752 & 53,100 \\
\hline $\mathrm{CO}_{2} \mathrm{e}-100 / \mathrm{kg}$ of meat $(\mathrm{kg})$ & 1.97 & 2.4 & 0.62 \\
\hline
\end{tabular}

Table 7 Manure management $\mathrm{N}_{2} \mathrm{O}$ and $\mathrm{CH}_{4}$ emissions converted to $\mathrm{CO}_{2} \mathrm{e}-100$ emissions per $\mathrm{kg}$ of meat produced

\begin{tabular}{lr}
\hline & $\mathrm{UK}_{1} \mathrm{UK}_{2}$ Brazil \\
\hline $\mathrm{CH}_{4}$ converted to $\mathrm{CO}_{2} \mathrm{e}-100 / \mathrm{kg}$ of meat & 1.972 .140 .62 \\
(kg/year) & \\
$\mathrm{N}_{2} \mathrm{O}$ converted to $\mathrm{CO}_{2} \mathrm{e}-100 / \mathrm{kg}$ of meat 3.554 .086 .98 \\
$(\mathrm{~kg} /$ year) & 5.526 .227 .70 \\
$\mathrm{CO}_{2} \mathrm{e}-100 / \mathrm{kg}$ of meat $(\mathrm{kg})$ & \\
\hline
\end{tabular}

cattle took into account data about diesel consumption and fertilizers spread on the fields. Information was collected and allocated to the respective meats produced taking into account the percentage of the crop or pasture used to feed the cattle. Data from other energy sources which could possibly be used in the farms was not considered in this study. This is because the farm unit "Brazil" did not possess grain drying and storage facilities. In the case of the farms in the UK, the records regarding this were incomplete. Hence, a more reliable comparison was not possible to be carried out. 
It has been also acknowledged that owed to low consumption of other energy sources in cattle production, these emissions would be negligible.

For diesel-related consumption emissions, the treatments applied to each of the fields throughout the farming, the years were classified into two categories: intense (e.g., ploughing, drilling, harvesting and manure spreading) and an estimated $8 \mathrm{~L}$ of diesel consumption per hectare was considered. As for the light treatment (e.g., topping and spraying), it was assumed some $3 \mathrm{~L}$ of diesel per hectare. Regarding the petrol-diesel emission factors in mobile combustion: $74,100 \mathrm{~kg}$ of $\mathrm{CO}_{2} / \mathrm{MJ}, 3.9 \mathrm{~kg}$ of $\mathrm{CH}_{4} / \mathrm{MJ}, 3.9 \mathrm{~kg}$ of $\mathrm{N}_{2} \mathrm{O} / \mathrm{MJ}$ and petrol-diesel were $36.4 \mathrm{MJ} / \mathrm{L}$ [23, 25]. As a result, an emission of $2.7425 \mathrm{~kg}$ of $\mathrm{CO}_{2} \mathrm{e}-100 \mathrm{~L}^{-1}$ of diesel consumed was adopted. No emissions from pesticide production and consumption were taken into account.

For emissions related to fertilizer consumption, emission factors associated to fertilizer use and manufacture are presented in Table 8.

The area for farm unit " $\mathrm{UK}_{1}$ " was 473.5 ha which were divided between crops and pasture fields with straw (*) being produced from arable crops except rapeseed and beans. The area of each crop and pasture, and the percentage used from the pasture and crop production/yield used for cattle production is presented in Table 9.

The area for farm unit " $\mathrm{UK}_{2}$ " was 240 ha which were divided between crops and pasture fields with the straw (*) being produced from arable crops except beans and oats. The area of each crop and pasture, and the percentage used from the pasture and crop production/yield used for cattle production is presented in Table 10.

The farm unit "Brazil" had 1,380 ha divided between crops and pasture fields. The area of each crop and pasture, and the percentage used from the pasture and crop production/yield used for cattle production is presented in Table 11. The area under soya production in the summer is used for oat and ray grass in the winter months.

The results for $\mathrm{CO}_{2} \mathrm{e}-100$ emission from each of the farms are presented in Table 12. Since throughout the calendar year, some animals were bought by each of the farms, compensation factors of 1.21 to " $\mathrm{UK}_{1}$ ", 1.08 to " $\mathrm{UK}_{2}$ " and 1.01 to "Brazil" farms units were used to compensate the emission related to cattle feeding in the supplier farm.

\section{6 “On Farm” Emissions Related to Inputs}

Beef cattle production is a relatively simple system of production where few inputs are brought into the farm other than fertilizers and diesel used for crops and pastures production. From the data collected from the farms, four different inputs, together with their emission factors, were detected to be inputs in cattle production, as shown in Table 13.

The minerals and salt emission factor was calculated based on the proportion of 50:50 between di-calciumphosphate and salt $(\mathrm{NaCl})$ which constitute the two major contents for this kind of product [26]. The embodied energy for both products has been expressed in $\mathrm{MJ} /$ ton [27] and was converted to $\mathrm{CO}_{2} \mathrm{e}-100$ equivalent by using petrol-diesel emission factor mentioned above as being the most common

Table 8 Emission factors for fertilizers and lime use and manufacture [23].

\begin{tabular}{lllll}
\hline & Type & Emission compound & Emission factor & Unit \\
\hline Use & $\mathrm{N}$ fertilizer & $\mathrm{N}_{2} \mathrm{O}$ & 0.0157 & $\mathrm{~kg} \mathrm{~N} \mathrm{O}^{\mathrm{kg} \mathrm{N}}$ \\
Use & Lime use & $\mathrm{CO}_{2}$ & 0.44 & $\mathrm{~kg} \mathrm{CO} / \mathrm{kg} \mathrm{limestone}$ \\
Manufacture & Ammonium nitrate & $\mathrm{CO}_{2}$ & 6,047 & $\mathrm{~kg} \mathrm{CO}_{2} \mathrm{e} /$ ton N \\
Manufacture & Urea & $\mathrm{CO}_{2}$ & 2,351 & $\mathrm{~kg} \mathrm{CO}_{2} \mathrm{e} /$ ton N \\
Manufacture & $\mathrm{N}$ in NPK & $\mathrm{CO}_{2}$ & 6,047 & $\mathrm{~kg} \mathrm{CO} 2 \mathrm{e} /$ ton N \\
Manufacture & $\mathrm{P}$ in NPK & $\mathrm{CO}_{2}$ & 2,261 & $\mathrm{~kg} \mathrm{CO}_{2} \mathrm{e} /$ ton $\mathrm{P}_{2} \mathrm{O}_{5}$ \\
Manufacture & $\mathrm{K}$ in NPK & $\mathrm{CO}_{2}$ & 326 & $\mathrm{~kg} \mathrm{CO}_{2} \mathrm{e} /$ ton $\mathrm{K}_{2} \mathrm{O}$ \\
\hline
\end{tabular}


Table 9 Farm unit "UK ${ }_{1}$ ” crop/pasture production areas and share used for cattle production.

\begin{tabular}{lcc}
\hline & Area (ha) & $\begin{array}{l}\text { Percentage for cattle } \\
\text { production }\end{array}$ \\
\hline Pasture (natural) & 76.90 & 100 \\
Natural grass for silage & 48.56 & 100 \\
Rapeseed & 68.80 & 0 \\
Winter barley & 40.47 & 33 \\
Spring barley & 6.07 & 0 \\
Winter wheat & 149.73 & 50 \\
Beans & 40.47 & 5 \\
Straw $(*)$ & 115.34 & 50 \\
Others & 42.50 & 0 \\
Total & 473.50 & \\
\hline
\end{tabular}

Table $10 \mathrm{UK}_{2}$ farm crops/pastures production areas and share used for cattle production.

\begin{tabular}{lcllr}
\hline & $\begin{array}{l}\text { Area } \\
\text { (ha) }\end{array}$ & $\begin{array}{l}\text { Percentage } \\
\text { production }\end{array}$ & for & cattle \\
\hline $\begin{array}{l}\text { Pasture (natural) } \\
\text { Natural grass for }\end{array}$ & 24 & 100 & \\
silage & 3.2 & 100 & \\
Natural grass for hay & 20 & 100 & \\
Ley for grazing & 15 & 100 & \\
Ley for silage & 21 & 100 & \\
Winter wheat & 38.8 & 0 & \\
Spring barley & 38.8 & 12.5 \\
Beans & 9.7 & 16.13 \\
Oats & 26.3 & 0 \\
Straw $(*)$ & 77.6 & 40 \\
Others & 43.2 & 0 \\
Total & 240 & & \\
\hline
\end{tabular}

Table 11 Farm unit "Brazil” crop/pasture production areas and share used for cattle production.

\begin{tabular}{lll}
\hline & Area (ha) & Percentage for cattle production \\
\hline Soya & 585.3 & 0 \\
Italian grass & 30 & 100 \\
Black oat & 278 & 50 \\
White oat & 82 & 50 \\
Pasture (natural) & 539.7 & 100 \\
Ray grass & 225 & 100 \\
Others & 100 & 0 \\
Total & 1,380 & \\
\hline
\end{tabular}

energy source used in the extraction, processing and transportation. For molasses, the emission factor was calculated based on the embodied energy in $\mathrm{MJ} / \mathrm{ton}$ and converted to $\mathrm{CO}_{2} \mathrm{e}-100$ equivalent [27]. The petrol-diesel emission factor was also considered for the molasses case. For soymeal, the emission factor calculation used the Brazil farm unit own soya production. Some $20 \%$ for the processing and another $66 \%$ was added regarding the emissions from the cultivation of soybean cultivation and transportation from Brazil to Europe [13]. Overall the consumption was 2,900 MJ/ton [22]. Compound feed emission factor used was based on $0.465 \mathrm{~kg}$ of $\mathrm{CO}_{2}$ per $\mathrm{kg}$ of feed [27].

The total amount of $\mathrm{CO}_{2} \mathrm{e}-100$ emissions related to farm inputs used for beef production in each farm is shown in Table 14.

\subsection{Slaughterhouse Emissions}

To calculate the emissions arising from the slaughter and meat processing, data was collected from two slaughterhouses, one in the United Kingdom (here named UK Slaughterhouse) and other in Brazil (here named Brazil Slaughterhouse). Usually, both farms in the UK have sold their cattle to the same slaughterhouse and the meat has gone, thereafter, to the same market. The only differences considered here relate to the distances between these farms and the slaughterhouse. Slaughterhouses emissions were calculated by quantifying the emissions from energy consumption, and allocating these emissions proportionally to the amount of carcass produced. For the purpose of this study, $87 \%$ of the slaughterhouse emissions were allocated to the carcasses produced based on the value of the carcass over the total value of the cattle products [28]. The electricity emission factors used in this study were $0.93371 \mathrm{~kg}$ of $\mathrm{CO}_{2} \mathrm{e}-100$ per MWh in Brazil and $0.47687 \mathrm{~kg}$ of $\mathrm{CO}_{2} \mathrm{e}-100$ per MWh in the UK as indicated [23, 29]. Diesel oil emission factor for stationary combustion used was $2.71 \mathrm{~kg}$ of $\mathrm{CO}_{2} \mathrm{e}-100 \mathrm{~L}^{-1}[23,25]$. Kerosene emission factor used for stationary combustion was $2.63 \mathrm{~kg}$ of $\mathrm{CO}_{2} \mathrm{e}-100$ per litre [23, 30]. Wood emission factor for stationary combustion used was $1,216 \mathrm{~kg}$ of $\mathrm{CO}_{2} \mathrm{e}-100$ per cubic meter [23, 25]. In Table 15, the slaughterhouse emissions, allocated to the meat produced, are shown according to the different energy 
Table $12 \mathrm{CO}_{2} \mathrm{e}-100$ emissions from crops/pasture production per hectare and per $\mathrm{kg}$ of meat produced.

\begin{tabular}{llll}
\hline & $\mathrm{UK}_{1}$ & $\mathrm{UK}_{2}$ & Brazil \\
\hline Area (ha) & 473.5 & 240 & 1380 \\
$\mathrm{CO}_{2} \mathrm{e}-100$ emissions (kg/year) & 581,047 & 246,239 & 521,441 \\
$\mathrm{CO}_{2} \mathrm{e}-100$ emissions from cattle production (kg/year) & 296,917 & 73,243 & 45,373 \\
$\mathrm{CO}_{2} \mathrm{e}-100$ emissions per hectare (kg/year) & $1,227.13$ & $1,025.99$ & 377.86 \\
$\mathrm{CO}_{2} \mathrm{e}-100$ emissions per kg of meat (kg) & 9.19 & 6.73 & 1.23 \\
\hline
\end{tabular}

Table 13 Inputs annual consumption per farm and emission factors.

\begin{tabular}{lllll}
\hline & $\mathrm{UK}_{1}(\mathrm{~kg} /$ year $)$ & $\mathrm{UK}_{2}(\mathrm{~kg} /$ year $)$ & Brazil $(\mathrm{kg} /$ year) & Emission factor $(\mathrm{kg}$ of CO2e-100/kg) \\
\hline Minerals and salt & 2,000 & 6,000 & 6,000 & 0.6028 \\
Molasses & 1,500 & 4,000 & 0 & 0.3436 \\
Soymeal & 8,000 & 0 & 0 & 0.4343 \\
Compound feed & 0 & 0 & 8,000 & 0.4650 \\
\hline
\end{tabular}

Table $14 \mathrm{CO}_{2} \mathrm{e}-100$ emissions related to inputs per $\mathrm{kg}$ of meat produced.

\begin{tabular}{llll}
\hline & $\mathrm{UK}_{1}$ & $\mathrm{UK}_{2}$ & Brazil \\
\hline Inputs related $\mathrm{CO}_{2} \mathrm{e}-100$ emissions (kg/year) & $5,195.41$ & $4,990.79$ & $7,336.52$ \\
Total carcass produced (kg/year) & 55,904 & 16,752 & 53,100 \\
$\mathrm{CO}_{2} \mathrm{e}-100$ emissions per kg of meat $(\mathrm{kg})$ & 0.13 & 0.42 & 0.20 \\
\hline
\end{tabular}

Table 15 Slaughterhouse $\mathrm{CO}_{2} \mathrm{e}-100$ emissions per kg of meat produced.

\begin{tabular}{lll}
\hline & UK Slaughterhouse & Brazil Slaughterhouse \\
\hline Electricity consumption (KWh/year) & $5,836,923$ & $4,604,052$ \\
Diesel consumption (L/year) & 118,755 & 0 \\
Kerosene consumption (L/year) & 55,269 & 0 \\
Wood consumption (m 3 /year) & 0 & 2,298 \\
Total kg of carcass processed (kg/year) & $19,764,000$ & $19,866,754$ \\
$\mathrm{CO}_{2} \mathrm{e}-100$ emissions per kg of meat $(\mathrm{kg})$ & 0.20 & 0.20 \\
\hline
\end{tabular}

sources consumption.

\subsection{Transport Emissions}

Emissions arising from transportation regarding the production of meat and supply chains were calculated according to the two types of transportion involved: road and marine transport. Distances between farms, slaughterhouses, the port, distribution centres and the market were calculated using Google Earth application. Approximation distances were considered by using straight lines between locations. The type of transportation and distances considered for the meat production and supply chains, according to each of the farms, are shown in Table 16.

For road transportation, distinct diesel consumptions catering for three types of vehicles under different road traffic conditions were considered and can be seen from Table 17. The emission factor for diesel consumption followed the same rationale as mentioned above, and considered $2.7425 \mathrm{CO}_{2} \mathrm{e}-100$ per litre of diesel consumed in mobile combustion [23, 25].

Only a negligible amount of rib meat produced by the UK slaughterhouse was not bone-free meat. As a result, that was not included in this study. All meat produced for the export market by the unit "Brazil slaughterhouse" was bone-free. Therefore, in the Brazilian case transportation after slaughterhouse was considered as refrigerated type of meat transportation, and $30 \%$ more fuel consumption for refrigerated transport was accounted [11]. In Table 18, the payloads weight for each track in each production and supply chain are shown. 
Table 16 Distance in the meat production and supply chains.

\begin{tabular}{lllll}
\hline Type & Description & Payload in tonnes & Average lts/100 km empty & Average lts/100 km loaded \\
\hline Light & Lorry distribution traffic & 8.5 & 22.5 & 27.5 \\
Medium & Lorry regional traffic & 14 & 27.5 & 35 \\
Heavy & Tractor and semi-trailer, long-haul traffic & 26 & 24.5 & 33.5 \\
\hline
\end{tabular}

Table 17 Road transport diesel consumption in the meat production and supply chains.

\begin{tabular}{|c|c|c|c|c|}
\hline Track & Type & $\mathrm{UK}_{1}$ & $\mathrm{UK}_{2}$ & Brazil \\
\hline Farm to slaughterhouse (km) & Heavy & 227 & 203 & 103 \\
\hline Slaughterhouse to port (km) & Heavy & no & no & 313 \\
\hline $\begin{array}{ll}\text { Slaughterhouse/port } & \text { to } \\
\text { distribution centre }(\mathrm{km}) & \end{array}$ & Medium & 187 & 187 & 41 \\
\hline $\begin{array}{l}\text { Distribution centre to market } \\
(\mathrm{km})\end{array}$ & Light & 70 & 70 & 7 \\
\hline
\end{tabular}

Table 18 Payload weights in each track.

\begin{tabular}{|c|c|c|c|}
\hline Track & $\mathrm{UK}_{1}$ & $\mathrm{UK}_{2}$ & Brazil \\
\hline $\begin{array}{l}\text { Farm to slaughterhouse ( } \mathrm{kg} \text { of live } \\
\text { weight) }\end{array}$ & 6,600 & 6,600 & 10,800 \\
\hline Slaughterhouse to port (kg of meat) & no & no & 26,000 \\
\hline $\begin{array}{l}\text { Slaughterhouse/port to distribution } \\
\text { centre (kg of meat) }\end{array}$ & 12,500 & 12,500 & 5,000 \\
\hline $\begin{array}{l}\text { Distribution centre to market ( } \mathrm{kg} \text { of } \\
\text { meat) }\end{array}$ & 8,500 & 8,500 & 2,000 \\
\hline
\end{tabular}

Table 19 Transport $\mathrm{CO}_{2} \mathrm{e}-100$ emission per $\mathrm{kg}$ of meat supplied.

\begin{tabular}{llll}
\hline & $\mathrm{UK}_{1}$ & $\mathrm{UK}_{2}$ & Brazil \\
\hline $\begin{array}{l}\text { Road transport } \mathrm{CO}_{2} \mathrm{e}-100 \text { emissions } \\
\text { per kg of meat }(\mathrm{kg})\end{array}$ & 0.0837 & 0.0795 & 0.0440 \\
$\begin{array}{l}\text { Marine Transport } \mathrm{CO}_{2} \mathrm{e}-100 \\
\text { emissions per kg of meat }(\mathrm{kg})\end{array}$ & no & no & 0.0740 \\
$\begin{array}{l}\text { Total Transport } \mathrm{CO}_{2} \mathrm{e}-100 \text { emissions } \\
\text { per Kg of meat }(\mathrm{Kg})\end{array}$ & 0.0837 & 0.0795 & 0.1179 \\
\hline
\end{tabular}

The total $\mathrm{CO}_{2} \mathrm{e}-100$ emissions arising from road transport for each production and supply chain were calculated using the data shown in Tables 16-18, and the result is summarized in Table 19, together with marine transportation emission. For marine transportation-related emissions, the emission factor of $0.07 \mathrm{~kg}$ of $\mathrm{CO}_{2} \mathrm{e}-100$ per ton per kilometre were used for a distance of 10,568 km between the oceanic port of Rio Grande in the state of Rio Grande do Sul in Brazil and Tilbury in the UK [31].

\section{Discussion and Conclusions}

When analysing the results of this study, it is noted that the larger source of greenhouse gases emissions in these meat production and supply chains studied is owed to enteric fermentation, with $66.6 \%$ of the emissions (Fig. 1).

As seen in Fig. 2, the second and third major sources are emissions having arisen from manure and crop/pasture management representing $17.2 \%$ and $15.9 \%$ of the total emissions, respectively. The emissions related to inputs, slaughter and transportation make up $1.5 \%$ of the total emissions.

When data from the farm units analyzed are compared against the regional average production, the "Brazil" farm unit produced on average $57.3 \mathrm{~kg}$ of carcass per head some $47.3 \%$ than the state's average at $38.89 \mathrm{~kg}$. Conversely, in the UK, the average quantity of carcass produced per head reared from both farms resulted in gains of $21.8 \%$ which was higher than the UK's national average at $104.4 \mathrm{~kg}$ and $85.68 \mathrm{~kg}$ of carcass per head, respectively. Despite these differences, it is possible to assert that the farms studied followed the same tendency as seen in other regions, where farms in the UK have demonstrated to operate under very efficient production systems (Table 20). Due to the lower productivity per unit of cattle in the area studied in Brazil, it is evident of its lower relative efficiency. When considering that the enteric emissions were the major source of GHG in beef production, we can assert that in the case of the state of Rio Grande do Sul the beef production system was characterised by higher emissions per unit of final product in relation to the UK system. This could be further emphasized, and the dairy production in both countries was considered as for the milk and beef production systems are much more interlinked in the UK than in Brazil. However, this was not the aim of this study.

Nonetheless, the greater productivity in the UK farm units also imposed a problem. The results obtained for 


\section{Meat $\mathrm{CO}_{2} \mathrm{e}-100$ emissions}

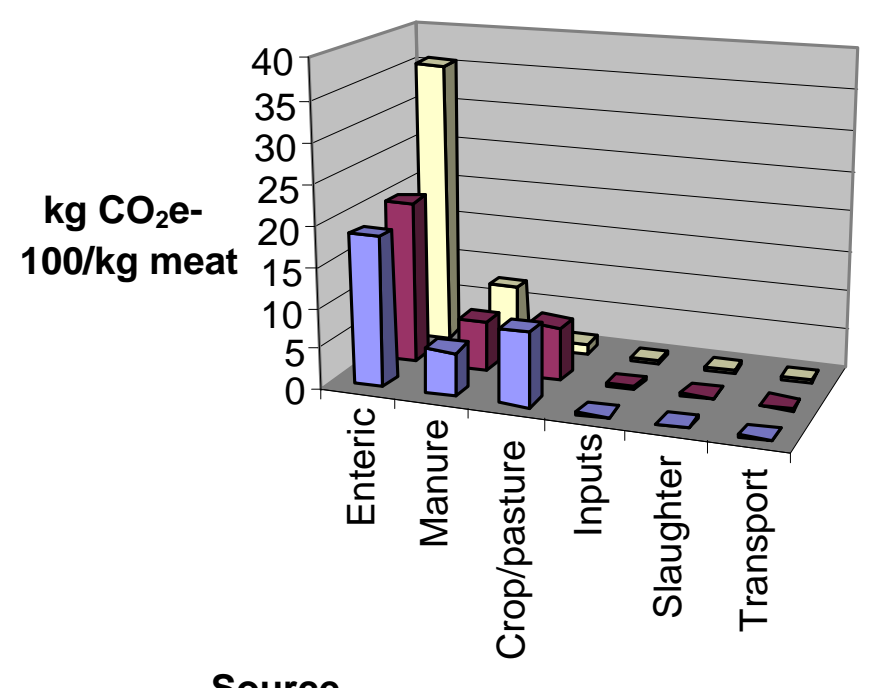

Source

Fig. 1 Total $\mathrm{CO}_{2} \mathrm{e}-100$ per $\mathrm{kg}$ of meat according the different sources.

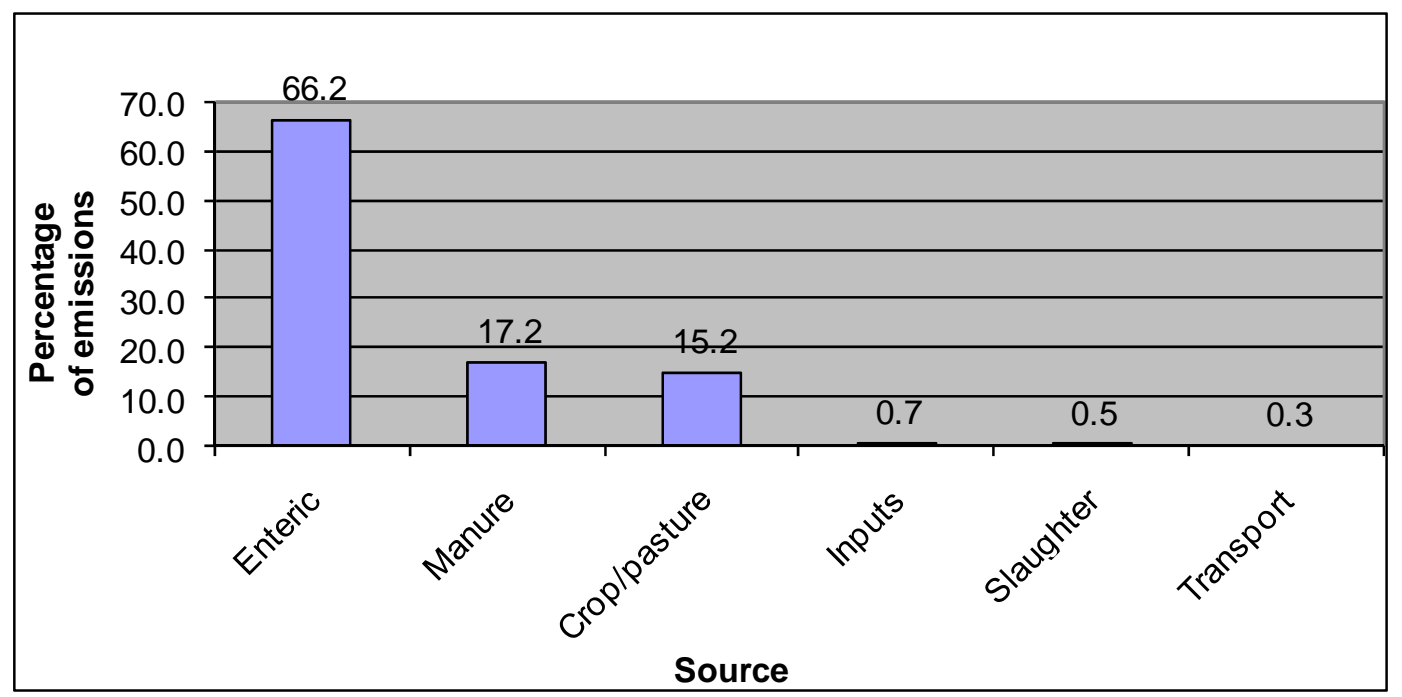

Fig. 2 Percentage of emissions from different sources.

emissions regarding crops and pasture production followed the average for the farm units in the UK, as being $7.96 \mathrm{~kg}$ of $\mathrm{CO}_{2} \mathrm{e}-100$ per $\mathrm{kg}$ of meat produced. On the other hand, the "Brazil" farm unit produced $1.23 \mathrm{~kg}$ of $\mathrm{CO}_{2} \mathrm{e}-100$ emission per $\mathrm{kg}$ of meat produced. It is notable that this greater productivity in the farm units in the UK has led to an increase in the overall emissions per hectare. This can be ascertained by analysing the data related to the emissions per hectare in Table 12 as being 1,227.13, 1,025.99 and $377.86 \mathrm{~kg}$ of $\mathrm{CO}_{2} \mathrm{e}-100 / h a$, for $\mathrm{UK}_{1}, \mathrm{UK}_{2}$ and Brazil farm units, respectively.

Moreover, the higher emissions from crops and pasture production were not sufficient to outweigh the increased emissions directly related to the cattle in less intensive system. The results of this study indicate that when increasing efficiency throughout intensification in cattle production systems would lead to a reduction 
Table 20 Cattle production systems comparison between the UK and the State of Rio Grande do Sul-Brazil.

\begin{tabular}{lll}
\hline & RS & UK \\
\hline Area (ha) & $28,174,854$ & $24,382,000$ \\
Bovine herd (heads) & $14,115,643$ & $10,107,000$ \\
Milked cows (heads/year) & $1,418,922$ & $1,935,000$ \\
Milk production (1000 L/year) & $3,314,573$ & $13,149,000$ \\
Milk produced per cow (L/year) & 2,336 & 6,795 \\
Cattle slaughtered (heads/year) & $2,596,696$ & $2,584,600$ \\
Average carcass weight (kg) & 211 & 335 \\
Carcass produced (1000 kg/year) & 548,941 & 866,000 \\
Percentage slaughtered yearly (\%) & 18 & 26 \\
kg of carcass produced/head (kg/head) & 38.89 & 85.68 \\
Natural grassland & $8,252,504$ & $6,036,000$ \\
\hline
\end{tabular}

Source: [18, 19, 32, 33].

in greenhouse gases emissions per functional unit of product. This is the case at least for the level of intensity of production of the farms studied. Further studies on this could include farm units under very intensive systems such as feedlots.

The emissions from enteric fermentation comprised of $75 \%$ of total emissions, against $66.2 \%$ found in this study [23]. In a study in Sweden it was comparatively lower than the one obtained for the UK farm units at $28.28 \mathrm{~kg}$ of $\mathrm{CO}_{2} \mathrm{e}$ per $\mathrm{kg}$ of bone-free meat in the Swedish case whilst the average for " $\mathrm{UK}_{1}$ " and " $\mathrm{UK}_{2}$ " farm units was $33.92 \mathrm{~kg}$ of $\mathrm{CO}_{2} \mathrm{e}$ per $\mathrm{kg}$ of meat reaching the market in London [6]. Moreover, in the study comparing the Argentine and German cases [12], such a low emission was owed to the size of the rural enterprises. The idea of an "Ecology of Scale" [34] was also evident in this study as the combined areas of the UK farm units make up half of the Brazil farm unit studied.

When the factor land-use change is removed [13], the results presented above are also in line with what was found in the "Interim Report Phase 1". Whilst the total amount from enteric fermentation was attributed to be $74 \%$ and total emission being $48 \mathrm{~kg} \mathrm{CO} 2 \mathrm{e} / \mathrm{kg}$ of meat, similar values were found in this study to be at $66.2 \%$ and $45.19 \mathrm{~kg}$ of $\mathrm{CO}_{2}$-e per $\mathrm{kg}$ of meat, respectively.

As seen from Figs. 1 and 2, the "Interim Report
Phase 1" also came to the conclusion that all other sources of GHG emissions in the production and supply chain of meat were negligible [13]. Instead of great transportation distances being a major environmental problem which would lead to higher carbon dioxide emissions [17], in agreement with this study, both cases contradicted the negative notion behind the food miles concept. Nonetheless, this study also showed that for the purpose of the UK market, locally produced meat had lower GHG emissions per $\mathrm{kg}$ of meat. It is very likely that the lower emission in the UK cases could be attributed to more increased productivity rather than distance food was transported.

As mentioned before, on farm food production systems are at the same time source of GHG emission and a sequestration point of carbon. In a recent review, the Food and Agriculture Organization of the United Nations, it was highlighted the potential for soil carbon sequestration in dry land grazing and its multiple benefits [14].

Estimations for the average potential carbon sequestration in grassland were calculated in this study [15]. Considering areas of natural grassland the farm units studied had 125.46 ha, 47.2 ha and 539.7 ha for "UK$K_{1}$ ", "UK ${ }_{2}$ " and "Brazil", respectively. When multiplying the $\mathrm{CO}_{2}$ sequestration potential by these areas, it would be possible to obtain an annual 248,411 $\mathrm{kg}$ of $\mathrm{CO}_{2}, 93,456 \mathrm{~kg}$ of $\mathrm{CO}_{2}$ and 1,068,606 $\mathrm{kg}$ of $\mathrm{CO}_{2}$ sequestered for the respective units. As for the carbon balance, if the potential carbon sequestered was deducted from the total emissions, it is possible to reach a final emission value of 29.4, 28.4 and $25.4 \mathrm{~kg}$ of $\mathrm{CO}_{2}$-e 100 per $\mathrm{kg}$ of bone-free meat for " $\mathrm{UK}_{1}$ ", "UK 2 " and "Brazil" farm units and supply chains, respectively. Although these are only hypothetical values, therefore further investigation is needed to calculate the balance between emissions and sequestration in meat production chains.

As for the farm management implications, emissions are directly related to the amount of meat produced per unit of cattle reared in the farms. Emissions are highly 
influenced by the weaning rate, age and carcass weight at slaughter. When the same methodology is used, and considering the estimated amount of cattle being kept in the farms, by reducing the age at slaughter from 30 months to 24 months, a reduction by $13 \%$ in emissions alone from both enteric and manure management could be achieved. Similarly, increasing the weaning rate of the Brazilian farm herd from $80 \%$ to $90 \%$, would reduce by $2 \%$ the enteric fermentation emission per $\mathrm{kg}$ of meat produced and by $3.2 \%$ the manure management related emissions. This is because a smaller number of cows would be needed to obtain the same number of calves. When combining the increase in weaning rate and the reduction in the age of slaughter, there would be a reduction by $15 \%$ of enteric and $17 \%$ of manure related emissions per $\mathrm{kg}$ of meat produced.

This study has been based on an inventory of beef production of three farm units which despite the small unit of study is very representative of a reality in beef supply chains. Further investigation is required to compare other farming systems.

\section{References}

[1] S. Goddard, Basic geology Part 2: $\mathrm{CO}_{2}$ in the atmosphere and ocean: What's up [Online], 2004, http://whatsupwiththat.com/2009/02/20/basic-geology-pa rt-2- $\mathrm{CO}_{2}$-in-the-atmosphere-and-ocean.

[2] Carbon Trust, Carbon Footprinting: An Introduction for Organization, 2007.

[3] J.W. Casey, N.M. Holden, A systematic description and analysis of GHG emissions resulting from Ireland's milk production using LCA methodology, Life cycle assessment in the agri-food sector, in: Proceedings from the 4th International Conference Bygholm, Denmark, [Online], 2003, http://www.lcafood.dk/lca_conf/ JFrapport_paper_2_poster.pdf.

[4] H. Steinfeld, P. Gerber, T. Wassenaar, V. Castel, M. Rosales, C. de Haan, Livestock's Long Shadow, Rome Food and Agriculture Organization-FAO, 2006.

[5] P. Forster, V. Ramaswamy, P. Artaxo, T. Berntsen, R. Betts, D.W. Fahey, et al., Changes in atmospheric constituents and in radiative forcing, in: Climate Change, The Physical Science Basis, Contribution of Working Group I to the Fourth Assessment Report of the Intergovernmental Panel on Climate Change, 2007.
[6] N. Stern, The Stern review-The economics of climate change, HM Treasury [Online], 2006 http://www.hm-treasury.gov.uk/sternreview_index.htm.

[7] T.J. Blasing, Recent greenhouse gas concentrations, Carbon Dioxide Information Analysis Center, Oak Ridge National Laboratory, US Department of Energy [Online], 2009, http://cdiac.ornl.gov.

[8] IPCC, Special Report on emissions scenario, Intergovernmental Panel on Climate Change-UNEP [Online], 2009, http://www.ipcc.ch/ipccreports/sres/emission/index.htm.

[9] B.P. Weidema, M. Thrane, S. Christensen, J. Schmidt, S. Lokke, Carbon footprint: A catalyst for life cycle assessment?, Journal of Industrial Ecology 12 (1) (2008) 3-6.

[10] M. Robert, Soil Carbon Sequestration for Improved Land Management, Food and Agriculture Organization-FAO, 2001.

[11] C. Cederberg, D. Meyer, A. Flysjö, Life Cycle Inventory of greenhouse gas emissions and use of land and energy of Brazilian beef exported to Europe. SIK-Rapport 792, SIK - Institutet för Livsmedel och Bioteknik, Göteborg, 2009, ISBN: 978-91-7290-283-1.

[12] E. Schlich, B. Hartert, F. Krause, Beef of Local and Global Provenience: A Comparison in Terms of Energy, $\mathrm{CO}_{2}$, Scale, and Farm Management in Conference Proceedings of the 6th, 2008.

[13] GGELS, European Greenhouse Gas Emissions from Livestock Production Systems, Project 2009, Joint Research Centre and European Commission, 2011.

[14] FAO, Review of evidence on drylands pastoral systems and climate change Implications and opportunities for mitigation and adaptation, Land and water discussion paper, 2009.

[15] R.T. Conant, K. Paustian, E.T. Elliott, Grassland management and conversion into grassland: Effects on soil carbon, Ecological Applications 11 (2) (2001) 343-355.

[16] G. Rebizter, T. Ekvall, R. Frischknecht, D. Hunkeler, G. Norris, T. Rydberg, et al., Life cycle assessment, part 1 : Framework, goal and scope definition, inventory analysis and applications, Environmental International v. 30 (2004) 701-720.

[17] P. Brenton, G. Edward-Lames, M.F. Jensen, Carbon labelling and low income country exports: An issue paper Munich Personal RePEc Archive-Paper No. 8971 [Online], 2008, http://mpra.ub.uni-muenchen.de/8971/.

[18] IBGE, Estadosat [Online], 2009, http://www.ibge.gov.br/estadosat/perfil.php?sigla=rs.

[19] DEFRA, Land use and livestock on agricultural holdings, England time series from 1992 [Online], 2001, http://www.defra.gov.uk/statistics/foodfarm/landuselivest ock/decembersurvey. 
[20] BSi, PAS-2050, The British Standard Institution [Online], 2008, http://www.bsi-global.com/en/Standards-and-Publication s/Industry-Sectors/Energy/PAS-2050/PAS-2050

[21] BSi, Guide to PAS-2050-How to Assess the Carbon Footprint of Goods and Services, The British Standard Institution [Online], 2008, http://www.bsi-global.com/en/Standards-and-Publication s/Industry-Sectors/Energy/PAS-2050/PAS-2050.

[22] C. Cederberg, A. Flysjo, Life Cycle Inventory of 23 Dairy Farms in South-western Sweden, The Swedish Institute for Food and Biotechnology, SIK-rapport Nr 728, 2004.

[23] IPCC, Guidelines for National Greenhouse Inventories, IGES, 2006.

[24] Weatherbase, Average temperatures [Online], 2009, http://www.weatherbase.com/about.php3.

[25] Bioenergy, Bioenergy conversion factors [Online], 2010, http://bioenergy.ornl.gov/papers/misc/energy_conv.html.

[26] C. Cederberg, U. Sonesson, J. Davis, V. Sund, Greenhouse gas emissions from production of meat, milk and eggs in Sweden 1990 and 2005, SIK-rapport 793, SIK-institutet för Livsmedel och Bioteknik, Göteborg, 2009, ISBN: 978-91-7290-284-8.

[27] C. Simmons, I. González, K. Lewis, Methodology for determining global sectorial material consumption, carbon dioxide emissions and ecological footprints, WWF, One Planet Business, Review Version 12 (2006).

[28] A. Chapagain, A. Hoekstra, Water footprints of nations, Main Report UNESCO-IHE, Delft, 2004.

[29] USDE, Appendix F. electricity emission factors foreign energy emission factors, US Department of Energy [Online], 2007, www.eia.doe.gov/oiaf/1605/pdf/appendix\%20F_r071023.

[30] Nickle's, Heating values, Nickle’s Energy, Information, Technology [Online], 2010, http://nickles.com/common/conv.asp.

[31] C. Saunders, A. Barber, G. Taylor, Food miles-comparative energy/emissions performance of New Zealand's agriculture industry, AERU, Research Report 285, 2006.

[32] FNP, Anuário da Pecuária Brasileira, Anualpec 2008, Instituto FNP, 2008.

[33] Agregar, Personal communication with the programme manager, 2009.

[34] E.H. Schlich, U. Fleissner, The ecology of scale: Assessment of regional energy turnover and comparison with global food, International Journal of Life Cycle Assessment 10 (2005) 212-223. 